\title{
Antibody Oriented Immobilization on Gold using the Reaction between Carbon Disulfide and Amine Groups and Its Application in Immunosensing
}

\author{
Yu Niu, ${ }^{\dagger}$ Ana I. Matos, ${ }^{\ddagger}$ Luisa M. Abrantes, ${ }^{\ddagger}$ Ana S. Viana, ${ }^{*}, \neq$ and Gang Jin ${ }^{*}{ }^{\dagger}$ \\ ${ }^{\dagger}$ NML, Institute of Mechanics, Chinese Academy of Sciences, 100190 Beijing, China \\ ${ }^{\ddagger} \mathrm{CQB}$, Department of Chemistry and Biochemistry, Faculty of Science, University of Lisbon, 1749-016 Lisbon, Portugal
}

Supporting Information

ABSTRACT: Carbon disulfide $\left(\mathrm{CS}_{2}\right)$ can spontaneously react with amine groups to form dithiocarbamates on gold surface, providing the possibility to immobilize some compounds with primary or secondary amine groups in one step. Using this principle, an immunosensor interface prepared for immunoglobulin $\mathrm{G}(\mathrm{IgG})$ sensing surface toward anti-IgG has been fabricated for the first time by simply immersing gold slides into a mixed aqueous solution of $\mathrm{CS}_{2}$ and protein $\mathrm{A}$, followed by incubation in immunoglobulin $\mathrm{G}$ solution. The reaction between $\mathrm{CS}_{2}$ and protein $\mathrm{A}$ has been followed by UV-vis spectroscopy, whereas cyclic voltammetry has been employed in the characterization of the modified gold surface with $\mathrm{CS}_{2}$ and protein $\mathrm{A}$, both methods indicating that protein $\mathrm{A}$ immobilization is implemented by $\mathrm{CS}_{2}$. Conventional ellipsometry, atomic force microscopy (AFM), as well as surface plasmon resonance (SPR) have been used to evaluate the specific binding of protein A with IgG and IgG with anti-IgG, revealing that IgG is specifically captured to form the biosensing interface, maintaining its bioactivity. Compared to direct adsorption of IgG on the gold surface, the IgG sensing surface constructed of $\mathrm{CS}_{2}$ and protein A is far more sensitive to capture anti-IgG as its target molecule. In addition, the modified surface is proven to have good capability to inhibit nonspecific adsorption, as supported by control experiments using lysozyme and BSA. To conclude, antibody immobilization using this one-step method has potential as a simple and convenient surface modification approach for immunosensor development.

\section{INTRODUCTION}

As the awareness to explore the mechanism of physiological events continues, biosensors as analytical devices that can determine biochemical and physiological changes have become powerful and rapidly developing tools for detection of biomolecule interactions. ${ }^{1-3}$ Immunosensors are one of the most promising biosensors, ${ }^{4-8}$ which use ligands to form their sensing surface to capture target analytes depending on biologically specific interactions and then transfer the recognition process to detectable physical or chemical signals. Since the sensing surface plays an important role for immunosensor performance, during the past decades, a lot of attention has been paid to this field to develop simple, effective, and practical biosensing interfaces. ${ }^{9,10}$ For immunosensors prepared on gold, alkanethiol-based self-assembled monolayers (SAMs $)^{11-17}$ are among the most popular surface modification strategies, because they can be easily prepared to form a highly organized and ultrastable organic thin film in nanometer scale with good reproducibility. ${ }^{15,18}$ If carboxylic functions are the terminal groups of SAMs, they can be used to covalently immobilize compounds with amine groups after an activation

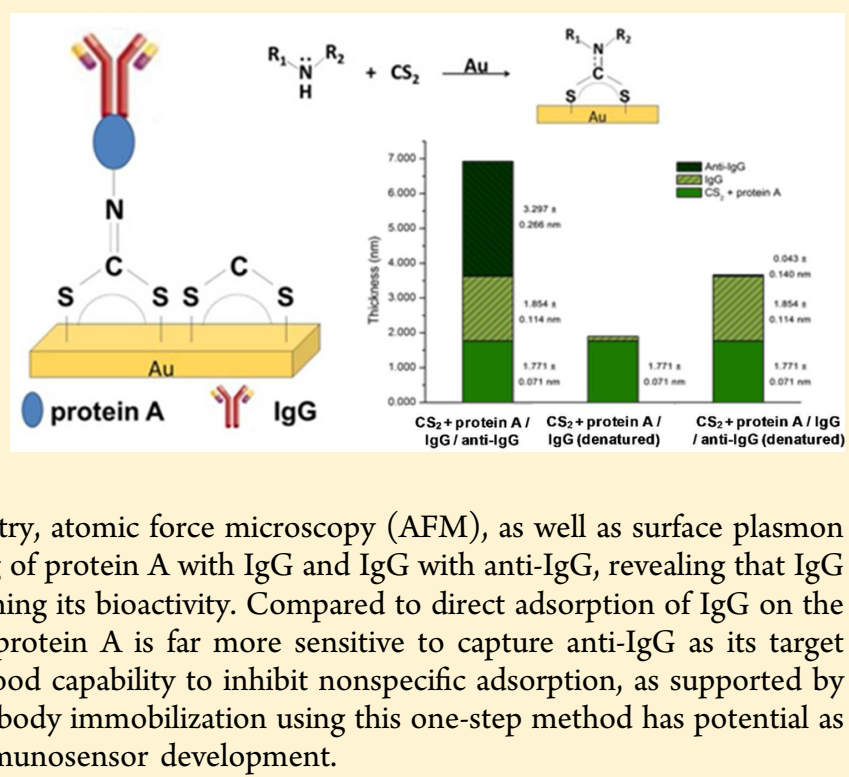

process, such as with $\mathrm{N}$-hydroxysuccinimide (NHS) and 1ethyl-3-(3-dimethylaminopropyl) carbodiimide (EDC). ${ }^{19,20}$

Dithiocarbamates (DTCs) which have been commonly used as chelating ligands in coordination chemistry monolayers ${ }^{21}$ provide an alternative to alkanethiol SAMs for gold surface modification. $^{22,23}$ The major structural characteristic of DTC is the resonance structure among $\mathrm{N}-\mathrm{C}-\mathrm{S}_{2}$, including both the sulfur-carbon bond and the carbon-nitrogen bond due to the free electron pairs on the sulfur and nitrogen atoms. ${ }^{24}$ Carbon disulfide can react with the amine group of a compound, forming DTC on a gold surface at room temperature. ${ }^{25-27}$ In that case, a compound with an amine group can be immobilized on a gold surface by simple immersion of the gold substrate in a solution containing $\mathrm{CS}_{2}$ and the target molecule. Compared to the alkanethiol-based SAMs modification method, its major advantage is that the gold surface modification and the ligand immobilization processes can be achieved in only one step. Therefore, it is not necessary to add some compounds, for

Received: July 26, 2012

Revised: December 4, 2012

Published: December 4, 2012 


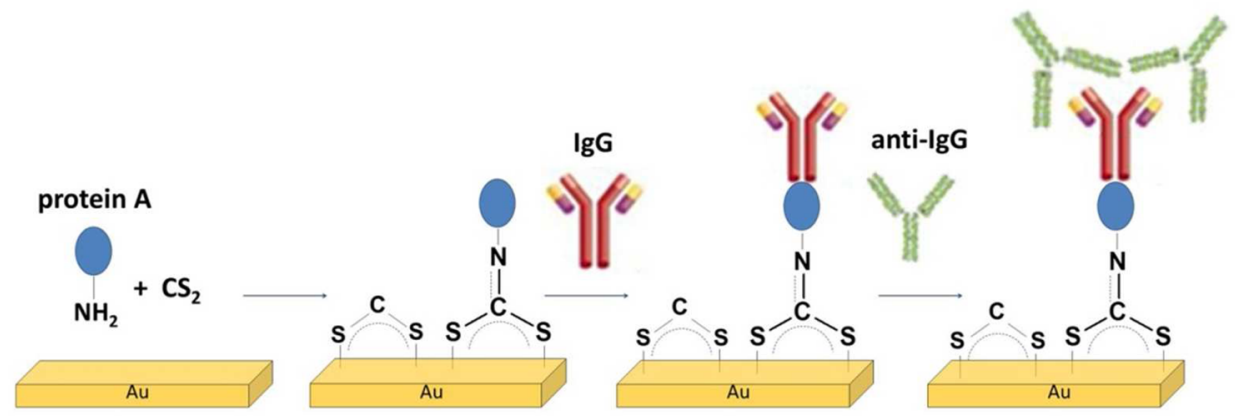

Figure 1. Schematic diagram of IgG immobilization on the gold surface modified with a solution of $\mathrm{CS}_{2}$ and protein A (the relative dimensions of $\mathrm{CS}_{2}$, protein $\mathrm{A}, \mathrm{IgG}$, and anti-IgG in this figure are distorted for clarity). First, a gold slide is immersed into a mixed solution of $\mathrm{CS}_{2}$ and protein $\mathrm{A}$, and then incubated in IgG solution in order to form the IgG sensing surface. Finally, incubation of the sensing surface in anti-IgG solution allows us to evaluate the bioactivity of the immobilized IgG.

instance, ECD and NHS, to activate SAM terminal functions for biomolecule covalent attachment. This procedure will not only save the expense of valuable chemicals, but also make the immobilization process more convenient by reducing the number of steps involved (gold modification with a linker, activation of terminal groups, and covalent linkage of the biomolecule). The method shows compelling potential for ligand immobilization in immunosensors employing gold surface as the substrate. Although there are some reported studies using this methodology, they are mostly focused on small molecules; ${ }^{25,28-33}$ for example, dopamine, epinephrine, different kinds of amino acid (e.g., tryptophan), and very few larger molecules, such as polyethyleneimine $(22 \mathrm{kDa})^{34}$ and biocompounds, namely, oligonucleotide ${ }^{35}$ and glucose oxidase, ${ }^{28}$ have been immobilized on gold by this new method. To our knowledge, this is the first study reporting the use of in situ DTC formation to prepare an immunosensing surface and clearly show its feasibility toward ligand detection and prevention of nonspecific adsorption.

The purpose of the present investigation is to prepare a new immunosensor interface with antibody probes using the in situ dithiocarbamate formation principle. IgG which often functions as the ligand for detecting analytes in commercial immunosensors is selected as a typical example of antibodies. Protein A commonly employed for an oriented immobilization of IgG is also used, since it contains several IgG binding domains and interacts specifically with the Fc portion of IgG exposing its bioactive Fab portion to further recognize anti-IgG molecules. ${ }^{36}$ The combined procedure of surface modification and IgG immobilization is illustrated in Figure 1. The bottom-up surface functionalization will be characterized by a combination of techniques including cyclic voltammetry, UV-vis spectroscopy, AFM, conventional ellipsometry, and SPR.

\section{EXPERIMENTAL SECTION}

2.1. Materials. $\mathrm{CS}_{2}$ is purchased from Sigma-Aldrich, and other chemicals, for instance, sulfuric acid (Pancreac), pure ethanol (Riedelde Häen), and sodium hydroxide (Fluka) are in analytical grade or better. Protein A from Staphylococcus aureus, human IgG, anti-human IgG from goat, lysozyme from chicken egg, bovine serum albumin (BSA), and blocking buffer are obtained from Sigma-Aldrich and used without further purification. Phosphate-buffered saline solution (PBS: $8.0 \mathrm{mmol} / \mathrm{mL} \mathrm{Na}_{2} \mathrm{HPO}_{4}, 1.14 \mathrm{mmol} / \mathrm{mL} \mathrm{KH}_{2} \mathrm{PO}_{4}, 138 \mathrm{mmol} / \mathrm{mL}$ $\mathrm{NaCl}$, and $2.7 \mathrm{mmol} / \mathrm{mL} \mathrm{KCl}, \mathrm{pH}=7.4)$ and phosphate-buffered saline solution with $0.05 \%$ Tween-20 (PBST, $\mathrm{pH}=7.4$ ) are purchased from Sigma-Aldrich and used for the preparation of biomolecule solution. Ultrapure water is obtained from a Milli-Q A10 gradient purification system $(18.2 \mathrm{M} \Omega \mathrm{cm}$ at room temperature) and used to prepare all the solutions.

2.2. Substrate Preparation. For electrochemistry, ellipsometry, and AFM measurements, gold film $(200 \mathrm{~nm})$ on borosilicate glass (prelayer of chromium, 2-4 nm) is purchased from Arrandee, and used as substrates for monolayer preparation. The surfaces are cleaned in piranha solution $\left(\mathrm{H}_{2} \mathrm{SO}_{4} / \mathrm{H}_{2} \mathrm{O}_{2}=3: 1, \mathrm{v} / \mathrm{v}\right)$ for a few minutes, and then washed with water and ethanol several times. After drying under pure nitrogen flow, they are flame-annealed under butane-oxygen to produce a flat surface with predominant (Au-111) crystallographic orientation. ${ }^{37}$

For SPR observations, gold $(50 \mathrm{~nm})$ coated glass slides are purchased from Analytical $\mu$-Systems and used as substrates. After washing with water and ethanol several times, they are placed in a UV cleaner for $25 \mathrm{~min}$ in order to remove any contamination.

2.3. Gold Surface Modification. Protein A is a highly stable cell surface receptor in Staphylococcus aureus. Its molecular weight is about $42 \mathrm{kDa}$ and contains four domains to bind the $\mathrm{Fc}_{\mathrm{c}}$ portion of IgG. ${ }^{38}$ In order to keep the Fab portion of IgG exposed outside, protein A is used to capture IgG. The experimental parameters (reaction times and reagent concentrations) for the reaction between $\mathrm{CS}_{2}$ and protein $\mathrm{A}$, in the presence of a gold surface, have been optimized and the best conditions are as follows: first, gold slides are immersed into a mixed solution $(1: 1, \mathrm{v} / \mathrm{v})$ of $0.1 \mathrm{M} \mathrm{CS}_{2}$ in water and $20 \mu \mathrm{g} / \mathrm{mL}$ protein $\mathrm{A}$ in PBS solution for $2 \mathrm{~h}$ at $4{ }^{\circ} \mathrm{C}$. After being thoroughly rinsed with water and dried by nitrogen, the slides are incubated in $100 \mu \mathrm{g} / \mathrm{mL}$ IgG in PBST solution for $30 \mathrm{~min}$, and then rinsed with PBST solution for 15 min at room temperature $\left(21 \pm 1{ }^{\circ} \mathrm{C}\right)$. Finally, the gold substrates are immersed in $100 \mu \mathrm{g} / \mathrm{mL}$ anti-IgG in PBST solution for $30 \mathrm{~min}$, also at room temperature. After rinsing with PBST solution for $15 \mathrm{~min}$, the substrates are washed with water and then dried with nitrogen. The concentrations of $\mathrm{CS}_{2}$, protein $\mathrm{A}, \mathrm{IgG}$, and anti-IgG, and reaction time were kept constant in all the experiments, unless noted otherwise.

2.4. UV-vis Spectrophotometry. UV-vis spectroscopy is obtained by a compact UV-2600 UV-vis spectrophotometer produced by Shimadzu Corporation. All measurements are performed under the absorbance mode over a scanning range from 200 to $600 \mathrm{~nm}$ with 2 nm intervals.

2.5. Morphological Investigations. The morphology of modified gold slides is characterized by a Nanoscope IIIa Multimode AFM produced by Digital Instruments (Veeco). All measurements are carried out using tapping-mode AFM with etched silicon tips $(\sim 300$ $\mathrm{kHz}$ ) in ambient conditions.

2.6. Ellipsometric Measurements. The measurement of the optical parameters and estimation of protein layer thickness is carried out by a conventional ellipsometry produced by SENTECH Instruments $\mathrm{GmbH}$. All measurements are performed with the angle of incidence at $70^{\circ}$ and a $\mathrm{He}-\mathrm{Ne}$ laser at $632.8 \mathrm{~nm}$.

To obtain the optical parameters of the bare gold, a two-phase model is used to deduce the refractive index $\left(n_{\mathrm{s}}\right)$ and adsorption coefficient $\left(k_{\mathrm{s}}\right)$. For measuring the thickness of the protein layer 
adsorbed on the gold surface, a three-phase model is employed. Assuming that the refractive index $\left(n_{\mathrm{u}}\right)$ of the protein layer is constant at $1.480,{ }^{39}$ the thickness $\left(T_{\mathrm{u}}\right)$ and extinction coefficient $\left(k_{\mathrm{u}}\right)$ could be deduced by data fitting process.

2.7. Electrochemical Studies. Cyclic voltammetry is carried out with a PARSTAT 2263 electrochemical workstation produced by AMETEK (Princeton Applied Research). A three-electrode Teflon cell is used for the electrochemical experiments. Gold slide, saturated calomel electrode (SCE), and a platinum wire are used as the working, reference, and counter electrode, respectively. The geometric area of the working electrode is about $0.57 \mathrm{~cm}^{2}$.

Electrochemical reductive desorption of sulfur from gold surfaces is performed with cyclic voltammetry experiment using $0.1 \mathrm{M} \mathrm{NaOH}$ as the electrolyte solution within a potential range of $0.0 \mathrm{~V}$ to $-1.1 \mathrm{~V}$ at the scan rate of $20 \mathrm{mV} \mathrm{s}^{-1}$, after degassing the solution with nitrogen for $1 \mathrm{~h}$.

2.8. SPR Sensor Monitoring. SPR measurements are carried out in a BIOSUPLAR $400 \mathrm{~T}$ compact SPR sensor produced by Analytical $\mu$-Systems. The real-time monitoring of protein adsorption and interaction is obtained using slope mode with the help of a syringe pump to control solution injection rate at $30 \mu \mathrm{L} / \mathrm{min}$.

\section{RESULTS AND DISCUSSION}

\subsection{Gold Surface Modification with $\mathrm{CS}_{2}$ and Protein} A. Alkanethiol SAMs bind intensively to gold surfaces by forming Au-sulfur bonds which can be quantitatively stripped from the gold electrode by electrochemical reductive desorption. This process is commonly carried out in strong alkaline solutions by cyclic voltammetry, and in general, a sharp peak occurs at negative potentials. ${ }^{19}$ Reductive desorption studies performed on modified gold substrates, which are immersed in an aqueous solution of $\mathrm{CS}_{2}$ and protein A (only with protein $\mathrm{A}$ or $\mathrm{CS}_{2}$ for the control experiments) for $2 \mathrm{~h}$, are presented in Figure 2. The corresponding peak potentials

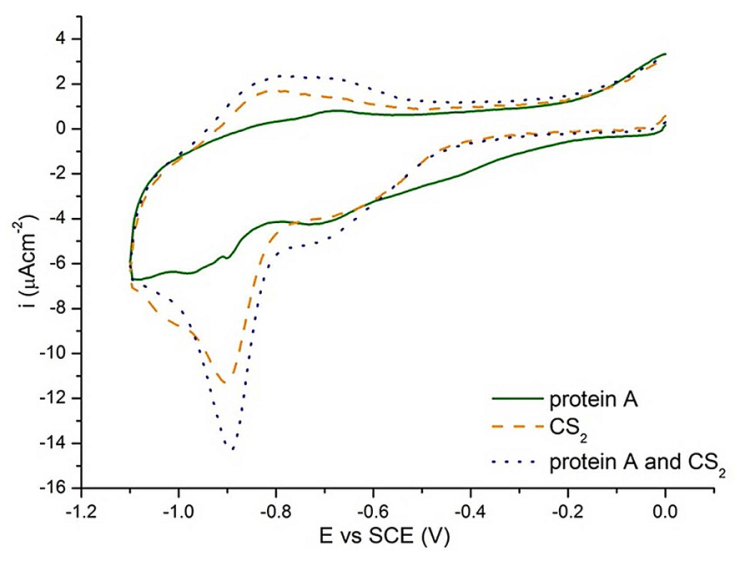

Figure 2. Cyclic voltammograms of the reductive desorption of sulfur from gold modified with protein $\mathrm{A}, \mathrm{CS}_{2}$, and protein $\mathrm{A}$ and $\mathrm{CS}_{2}$ in aqueous solutions, performed in $0.1 \mathrm{M} \mathrm{NaOH}$ at $20 \mathrm{mV} \mathrm{s}^{-2}$.

$\left(E_{\mathrm{p}}{ }^{\mathrm{red}}\right)$ as well as its estimated sulfur density $(\Gamma)$ based on the integration of the cathodic peak area, considering the transfer of one electron per $\mathrm{CS}_{2}$ or $\mathrm{DTC}^{23}$ desorbed molecules, are presented in Table 1 . The cyclic voltammogram of protein A adsorbed directly on gold does not exhibit any remarkable cathodic feature within the studied potential range, whereas a significant reduction peak emerges at $-0.89 \mathrm{~V}$ and $-0.90 \mathrm{~V}$ for the gold substrates modified with protein $\mathrm{A}$ and $\mathrm{CS}_{2}$ or only $\mathrm{CS}_{2}$, respectively. However, the intensity and charge involved in the sulfur stripping peak when gold is modified with protein $\mathrm{A}$ and $\mathrm{CS}_{2}$ increases considerably compared to that of just $\mathrm{CS}_{2}$.
Table 1. Peak Potential and Deduced Sulfur Density Obtained from the Cyclic Voltammograms Shown in Figure 2

$\begin{array}{cccc} & \mathrm{CS}_{2} & \text { protein } \mathrm{A} & \mathrm{CS}_{2}+\text { protein } \mathrm{A} \\ E_{\mathrm{p}}^{\text {red }} / \mathrm{V} & -0.90 & \mathrm{NA} & -0.89 \\ \Gamma^{a} / \mathrm{mol} \mathrm{cm}^{-2} & 4.0 \times 10^{-10} & \mathrm{NA} & 5.6 \times 10^{-10} \\ { }^{a} \text { Assuming } 1 \mathrm{e}^{-} \text {per desorbed molecule } & \left(\mathrm{CS}_{2} \text { or } \mathrm{DTC}^{23}\right)\end{array}$

This could be the result of higher solubility of the dithiocarbamate formed between $\mathrm{CS}_{2}$ and protein $\mathrm{A}$ in water than that of the pure $\mathrm{CS}_{2}$, thus promoting the sulfur adsorption. The shape of this desorption peak and its potential reflect the layer stability, and are dependent on several factors such as the type of sulfur species and packing density. The reduction potentials observed for the gold slides modified with only $\mathrm{CS}_{2}$ or $\mathrm{CS}_{2}$ and protein $\mathrm{A}$ are shifted toward negative values, regarding the desorption of short thiol derivatives (commonly around $-0.8 \mathrm{~V}$ ), revealing the good stability of the resonant structure between the sulfur and the carbon. ${ }^{40}$ It should be pointed out that the high amount of deposited sulfur on gold (Table 1) upon the reaction of $\mathrm{CS}_{2}$ and protein A strongly suggests that DTC immobilization is accompanied by the coadsorption of $\mathrm{CS}_{2}$ molecules that did not react with protein $\mathrm{A}$, as exemplified in the scheme of Figure 1. The voltammetric results suggest that it is possible to modify a gold electrode by one-step reaction of $\mathrm{CS}_{2}$ and protein $\mathrm{A}$ in aqueous solutions for only $2 \mathrm{~h}$.

UV-vis spectroscopy has been used to characterize the reaction between protein $\mathrm{A}$ and $\mathrm{CS}_{2}$ in aqueous solution, and the data are shown in Figure 3. The spectra of $\mathrm{CS}_{2}$ and protein

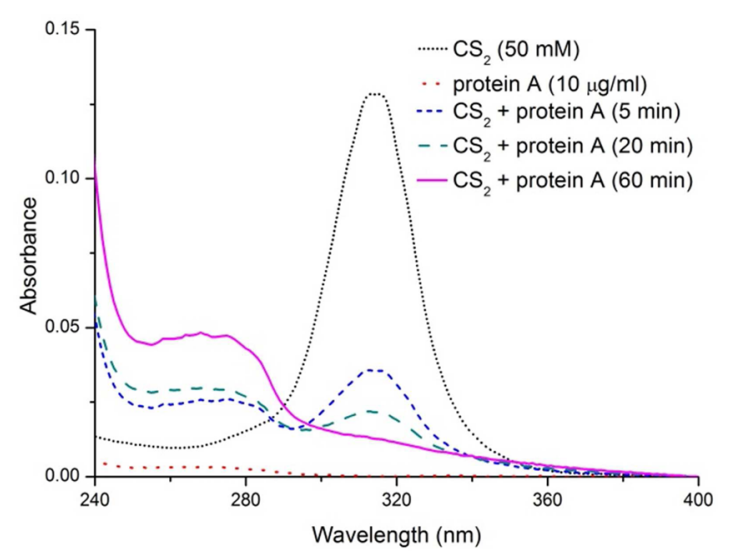

Figure 3. UV-vis spectroscopy of $\mathrm{CS}_{2}$, protein $\mathrm{A}$, and their mixture in aqueous solution.

A under the same conditions are included for comparison. Protein A is a single-chain polypeptide with a molecular weight of $42 \mathrm{kDa}$, containing about 472 amino acid residues (rich in lysine) to form 4 repetitive domains. ${ }^{38}$ Thus, it provides different amine groups, both primary ${ }^{31}$ and secondary ${ }^{26}$ in side chains, which are known to react with $\mathrm{CS}_{2}$ to form DTC groups. $^{25,26,31,32}$ Because protein $\mathrm{A}$ is completely devoid of tryptophan and contains only few phenylalanine and tyrosine residences in its structure, its UV-vis absorption spectroscopy does not present clear peaks between 260 and $280 \mathrm{~nm}$ at low concentrations, ${ }^{41}$ which is helpful to observe the appearance of absorption bands of DTC in a similar wavelength range. $\mathrm{CS}_{2}$ exhibits a characteristic peak near $315 \mathrm{~nm}$, for which the 
intensity decreases remarkably over time in the presence of protein $\mathrm{A}$. The disappearance of this peak after $1 \mathrm{~h}$ indicates that $\mathrm{CS}_{2}$ has been consumed by reaction with protein $\mathrm{A}$ in aqueous solution. Meanwhile, a wide and obvious band at wavelength ranging from 250 to $290 \mathrm{~nm}$ forms gradually. It is well-known that DTCs have two characteristic UV absorption peaks at approximately $260 \mathrm{~nm}$ and at $290 \mathrm{~nm}$, which can be clearly depicted when DTC is formed from $\mathrm{CS}_{2}$ and a single amino acid $^{28,31}$ or smaller compounds. ${ }^{25}$ However, these two characteristic peaks can shift depending on the structure of the side chain. ${ }^{30-32,42}$ Considering the large number and different amine groups present in protein $\mathrm{A}$, the wide peak should correspond to distinct DTC, providing evidence for protein ADTC formation by mixing protein $\mathrm{A}$ and $\mathrm{CS}_{2}$ in aqueous solution. When DTC is formed in the presence of a gold substrate, it is very likely that sulfur atoms will ready interact with the surface to become stably adsorbed.

The stability of protein $\mathrm{A}$ immobilized by $\mathrm{CS}_{2}$ in one step (mixing protein $\mathrm{A}$ and $\mathrm{CS}_{2}$ together to form DTC) has been analyzed by ellipsometry (Figure 4) through the evaluation of

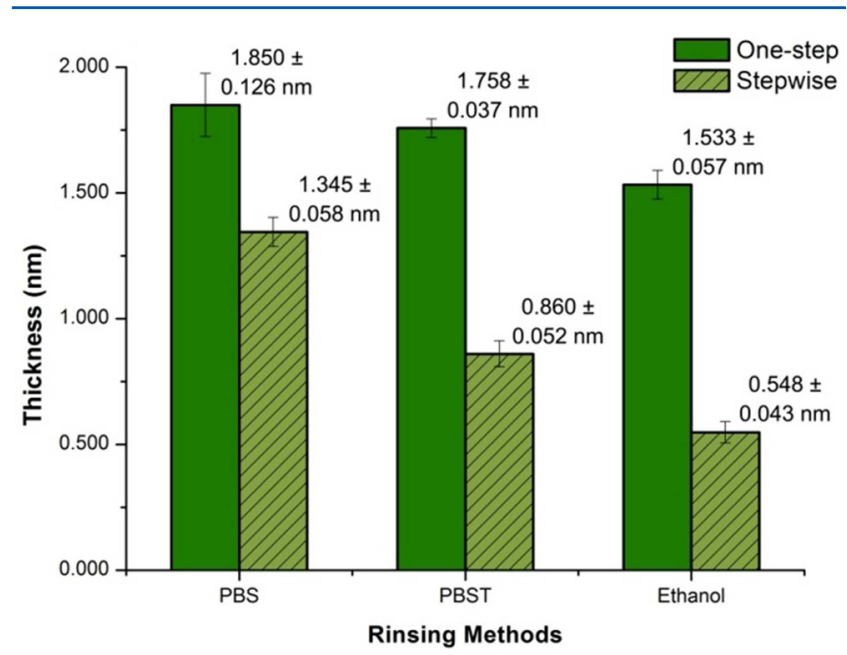

Figure 4. Stability of protein A immobilized by one-step (immersing gold slide in the mixed solution of $\mathrm{CS}_{2}$ and protein $\mathrm{A}$ ) and stepwise methods (physical adsorption of protein $\mathrm{A}$ on $\mathrm{CS}_{2}$ modified surface).

layer thickness and compared with a stepwise-prepared gold slide (physical adsorption of protein $\mathrm{A}$ on a $\mathrm{CS}_{2}$ modified surface). Upon PBS rinsing, the thickness of protein A adsorbed by one-step method $(1.850 \mathrm{~nm})$ is larger than that of stepwise procedure $(1.334 \mathrm{~nm})$, indicating that a higher amount of protein A can be immobilized by using a one-step method. Tween-20 is an effective detergent to remove physical adsorption and is commonly used in biological experiments to inhibit nonspecific adsorption. ${ }^{43}$ After protein $\mathrm{A}$ is assembled on gold slides by both one-step and stepwise methods, these slides are placed into PBST buffer for $30 \mathrm{~min}$, separately. In comparison to the stepwise method, the layer thickness decrease is minor for one-step preparation, supporting the presence of a covalent binding between $\mathrm{CS}_{2}$, protein $\mathrm{A}$, and gold. Further washing with ethanol leads to a significant decrease $(59.25 \%)$ of the thickness in the case of protein A prepared by the stepwise method with a change of $0.797 \mathrm{~nm}$, and again only a slight change (17.13\%) has been detected for the gold modified by one-step protein A binding.

The resistance of protein A immobilized by one step and the damage of physical adsorption by stepwise in ethanolic environment suggests protein A is strongly attached to gold surface by $\mathrm{CS}_{2}$ most probably through DTC linkage rather than direct physical adsorption.

3.2. IgG Immobilization and anti-IgG Capture. After modification with $\mathrm{CS}_{2}$ and protein $\mathrm{A}$, the gold surface is immersed in the IgG PBST solution to form an IgG biosensing surface. Then, anti-IgG is used to evaluate the bioactivity performance of the immobilized IgG. These biological recognition events are monitored by AFM, conventional ellipsometry, and SPR.

The morphology of the modified gold slides with $\mathrm{CS}_{2}$ and protein $\mathrm{A}$, upon further incubation in $\mathrm{IgG}$ solution and finally after contact with anti-IgG solution, has been characterized by AFM (Figure 5). In Figure 5A, individual molecules or very

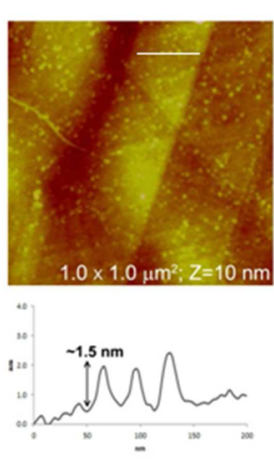

(A) $\mathrm{Au} / \mathrm{CS}_{2}+$ protein $\mathrm{A}$

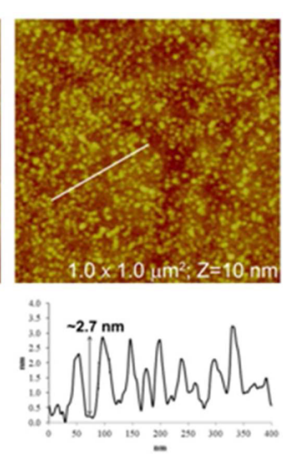

(B) $\mathrm{Au} / \mathrm{CS}_{2}+$ protein $\mathrm{A}$

I IgG

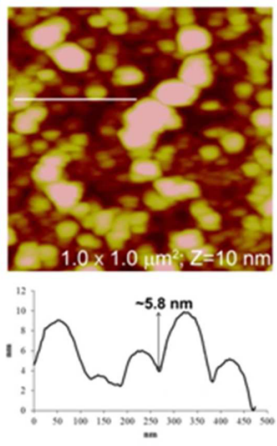

(C) $\mathrm{Au} / \mathrm{CS}_{2}+\operatorname{protein} \mathrm{A}$

/ IgG / anti-lgG
Figure 5. AFM images and their profiles of Au (111) modified with $\mathrm{CS}_{2}$ and protein A (A), then incubated in IgG (B) and finally with anti-IgG solution (C).

small aggregates of protein A can be observed that are only partially covering the gold surface. Although the typical gold monatomic steps are still visible, it is expected that a very thin layer of $\mathrm{CS}_{2}$ molecules (not clearly detectable with tapping mode AFM in this scale) are surrounding protein A, as suggested by electrochemical results and also by the ellipsometric data discussed below. After incubation in IgG solution, it is clear that the antibody is bound to the gold surface modified by $\mathrm{CS}_{2}$ and protein A (Figure 5B), yet not covering the whole surface, with good distribution to keep some necessary spaces to capture more anti-IgG molecules. Upon immersion in anti-IgG solution (Figure 5C), both the size and the density of the protein complexes change significantly. The spaces left on the gold surface are drastically reduced and protein molecules overlap each other in some positions. The corresponding section analysis with average vertical particle size (obtained from more than 25 profiles for each image) is included below each image of Figure 5. Although qualitative, these values clearly show an increase in both particle axial and lateral size, as the result of surface modification with IgG and anti-IgG.

The ellipsometric parameters obtained for bare and modified gold (average of at least 5 independent measurements) and estimated thicknesses are represented in Figure 6 and compiled in Table 2, confirming the surface density increase after each modification step.

The average layer thickness for $\mathrm{CS}_{2}$ and protein $\mathrm{A}, \mathrm{IgG}$, and anti-IgG are 1.771, 1.854, and $3.297 \mathrm{~nm}$, respectively. It indicates that not only is protein A immobilized on gold surface, but IgG can also be connected to protein $A$ and 


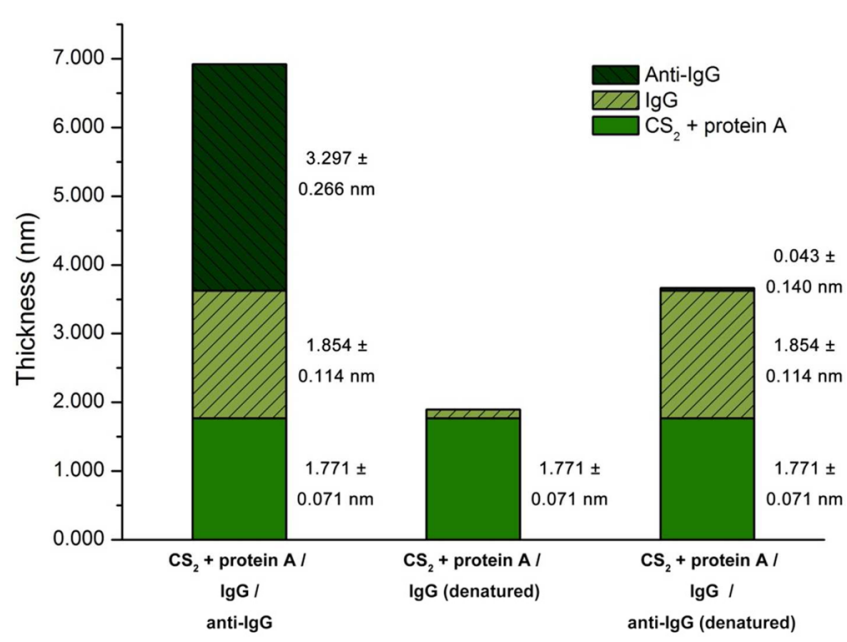

Figure 6. Ellipsometric results of $\operatorname{IgG}$ and anti-IgG binding on modified gold surfaces.

Table 2. Ellipsometric Results of IgG and anti-IgG Binding on Modified Gold Surfaces

\begin{tabular}{|c|c|c|c|}
\hline surface & $\Psi /^{\circ}$ & $\Delta /^{\circ}$ & $\tau / \mathrm{nm}^{a}$ \\
\hline $\mathrm{Au}$ & $43.764 \pm 0.031$ & $109.505 \pm 0.134$ & \\
\hline $\begin{array}{l}\mathrm{Au} / \mathrm{CS}_{2}+ \\
\text { protein } \mathrm{A}\end{array}$ & $43.613 \pm 0.011$ & $107.582 \pm 0.043$ & $1.771 \pm 0.071$ \\
\hline $\begin{array}{l}\mathrm{Au} / \mathrm{CS}_{2}+\text { protein } \\
\mathrm{A} / \mathrm{IgG}\end{array}$ & $43.632 \pm 0.010$ & $105.677 \pm 0.021$ & $3.625 \pm 0.089$ \\
\hline $\begin{array}{l}\mathrm{Au} / \mathrm{CS}_{2}+\text { protein } \\
\mathrm{A} / \mathrm{IgG} / \text { anti- } \\
\mathrm{IgG}\end{array}$ & $43.658 \pm 0.014$ & $102.416 \pm 0.073$ & $6.922 \pm 0.251$ \\
\hline $\begin{array}{l}\mathrm{Au} / \mathrm{CS}_{2}+\text { protein } \\
\mathrm{A} / \mathrm{IgG} \\
\text { (denatured) }\end{array}$ & $43.622 \pm 0.018$ & $107.455 \pm 0.125$ & $1.897 \pm 0.117$ \\
\hline $\begin{array}{c}\mathrm{Au} / \mathrm{CS}_{2}+\text { protein } \\
\mathrm{A} / \mathrm{IgG} / \text { anti- } \\
\text { IgG } \\
\text { (denatured) }\end{array}$ & $43.658 \pm 0.009$ & $105.639 \pm 0.013$ & $3.668 \pm 0.108$ \\
\hline $\begin{array}{l}\mathrm{Au} / \mathrm{CS}_{2}+\text { protein } \\
\mathrm{A} / \text { lysozyme }\end{array}$ & $43.620 \pm 0.010$ & $107.496 \pm 0.022$ & $1.857 \pm 0.078$ \\
\hline $\begin{array}{l}\mathrm{Au} / \mathrm{CS}_{2}+\text { protein } \\
\text { A/BSA }\end{array}$ & $43.634 \pm 0.026$ & $107.568 \pm 0.061$ & $1.793 \pm 0.094$ \\
\hline \multicolumn{4}{|c|}{$\begin{array}{l}a_{\text {Thickness values were predicted as described in the Experimental }} \\
\text { Section by fixing the refractive index. The estimated extinction } \\
\text { coefficient values (ranging from } 0.010 \text { to } 0.145 \text { ) indicate near } \\
\text { transparent films, as expected for thin protein layers. }\end{array}$} \\
\hline
\end{tabular}

maintain its bioactivity to capture anti-IgG. By AFM imaging, one can see that protein $\mathrm{A}$ is only occupying part of the gold surface after incubation in the mixed solution of $\mathrm{CS}_{2}$ and protein $\mathrm{A}$, and therefore, the layer thickness obtained by ellipsometry is intimately related with surface density. It is an average result of the optical parameters of the probed area (about $1 \mathrm{~mm}^{2}$ ), covered by the incidence light, which certainly corresponds to a much lower thickness than that expected for fully packed protein layer.

Nonspecific adsorption is one of the major limitations associated with immunosensing systems based on thickness or mass changes. In order to ascertain the ability of the novel goldmodified surface to reduce or inhibit the side effects of nonspecific adsorption, denatured IgG and denatured anti-IgG have been brought as negative controls to confirm the specific binding between protein A with $\operatorname{IgG}$ and IgG with anti-IgG. The corresponding results are shown in Table 2 and Figure 6. On the gold surface modified with $\mathrm{CS}_{2}$ and protein $\mathrm{A}$, the layer thickness increases from 1.771 to $1.897 \mathrm{~nm}$ after the injection of denatured IgG solution under the same conditions as native IgG. The thickness increase caused by denatured IgG is only $0.126 \mathrm{~nm}$, which is less than one-tenth of that of native IgG $(1.854 \mathrm{~nm})$. It is proven that IgG should be mainly bound to the modified gold surface by its specific interaction with protein A rather than direct adsorption or nonspecific adsorption to the gold surface modified with $\mathrm{CS}_{2}$. After the addition of denatured anti-IgG on the IgG sensing surface prepared on $\mathrm{CS}_{2}$ and protein A modified gold, the thickness increases only $0.043 \mathrm{~nm}$, which is far less than that obtained by the addition of native anti-IgG. It means that denatured anti-IgG cannot bind to the IgG sensing surface by nonspecific adsorption. In that case, the observed increase upon native anti-IgG addition can be assigned to the specific biorecognition between IgG and antiIgG. On the other hand, it can be foreseen that even though a blocking agent is not introduced yet, the modified surface presents a good potential to prevent the effect of nonspecific adsorption. We have previously verified that once $\mathrm{CS}_{2}$ is immobilized on gold its reaction toward amine groups from solution is drastically reduced; therefore, the presence of a thin organic layer of $\mathrm{CS}_{2}$ surrounding protein A-DTC should be responsible for the prevention of nonspecific adsorption.

SPR measurements are also conducted to monitor IgG immobilization on the surface modified by $\mathrm{CS}_{2}$ and protein $\mathrm{A}$ and further anti-IgG capture by IgG. Figure 7 shows a

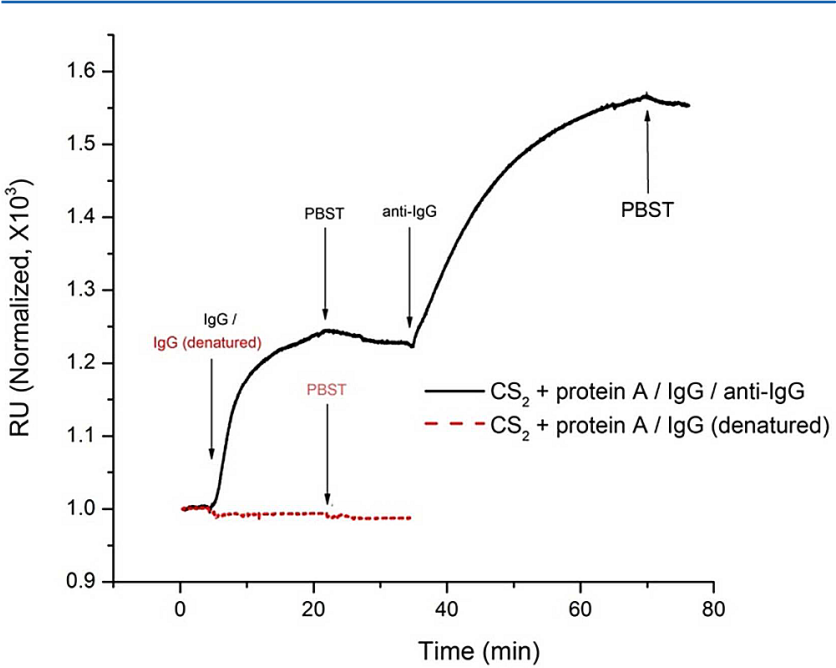

Figure 7. Real-time results of SPR sensor in slope mode for IgG and anti-IgG binding on the modified surface.

representative SPR experiment where the whole process is recorded in slope mode to obtain a real-time curve. The gold slides are treated with the mixed solution of $\mathrm{CS}_{2}$ and protein $\mathrm{A}$ as described in section 2.3, and then placed in the SPR flow cell. After the injection of $\operatorname{IgG}$ solution $(27 \mu \mathrm{g} / \mathrm{mL})$ and cleaning with PBST, the signal increases about $245 \mathrm{RU}$, while it rises about $355 \mathrm{RU}$ with the addition of anti-IgG $(13 \mu \mathrm{g} / \mathrm{mL})$ followed by rinsing with buffer solution. Instead, when denatured $\mathrm{IgG}$ is used as the negative control, the signal almost maintains the same level after its addition. By comparing both SPR responses, the increase in the signal suggests that IgG is immobilized on the surface modified with $\mathrm{CS}_{2}$ and protein $\mathrm{A}$ to form the biorecognition sensing interface and anti-IgG can be bound specifically to surface IgG, corroborating the ellipsometric data. 
3.3. Biosensing Surface Performance. The performance of the biosensing interface is evaluated by the amount of antiIgG captured by the modified surface and the capability of inhibiting nonspecific adsorption.

The capability of capturing anti-IgG is not only an indicator of the IgG bioactivity, but also a key factor to the sensitivity of the biosensing interface. Anti-IgG ranging from $12.5 \mu \mathrm{g} / \mathrm{mL}$ to $100 \mu \mathrm{g} / \mathrm{mL}$ has been added to the following modified gold surfaces: direct adsorption of $\mathrm{IgG}$, mixed solution between IgG and $\mathrm{CS}_{2}$ (absence of protein $\mathrm{A}$ ), and IgG interaction with $\mathrm{Au} /$ $\mathrm{CS}_{2}$ and protein $\mathrm{A}$, under the same conditions. In order to decrease the influence caused by nonspecific adsorption on bared and modified gold surface, blocking buffer has been introduced before the addition of anti-IgG solution at different concentration. The layer thickness of anti-IgG captured by the biosensing interface are deduced by ellipsometry (Table S1, Supporting Information) and compared in Figure 8. The results

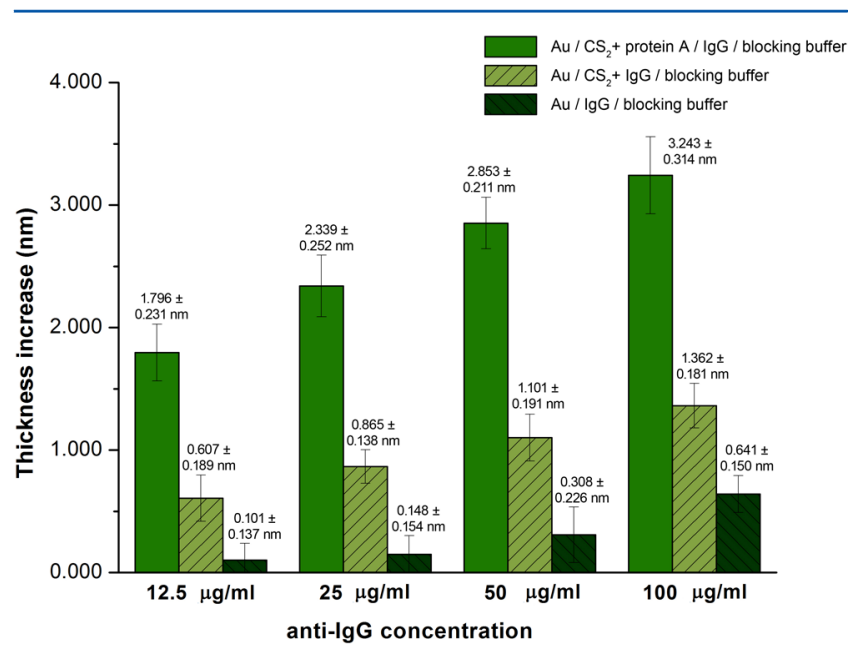

Figure 8. Amount of anti-IgG captured by the modified biosensing interface. Estimated layer thickness values obtained by ellipsometry for the different investigated surfaces.

clearly show for all the anti-IgG concentrations studied that, when IgG is assembled on the gold surface modified with $\mathrm{CS}_{2}$ and protein $\mathrm{A}$, many more anti-IgG molecules are recognized by the surface, as reflected by higher thickness values than those obtained for the other surface modification methodologies. In addition, the response, augmenting the anti-IgG concentration from $12.5 \mu \mathrm{g} / \mathrm{mL}$ to $100 \mu \mathrm{g} / \mathrm{mL}$, leads to a notorious increase of the corresponding thickness, suggesting that the dynamic range for anti-IgG detection can also be guaranteed. Thus, it can be foreseen that the use of in situ dithiocarbamate formation between $\mathrm{CS}_{2}$ and protein A may be successfully employed in the construction of immunosensor platforms.

Nonspecific adsorption may significantly cover the specific signal and further disturbs the detection conclusion. The capability to inhibit nonspecific adsorption of the gold surface modified by $\mathrm{CS}_{2}$ and protein A was not only tested by the addition of denatured IgG and denatured anti-IgG (section 3.2), but also carried out toward two typical proteins. After modification with the mixed solution of $\mathrm{CS}_{2}$ and protein $\mathrm{A}$, gold slides are immersed in lysozyme solution $(1.0 \mathrm{mg} / \mathrm{mL})$ or BSA solution $(1.0 \mathrm{mg} / \mathrm{mL})$ for $30 \mathrm{~min}$, then washed with PBST. The ellipsometric results are listed in Table 2 and the estimated thicknesses are shown in Figure 9. The layer thickness caused by nonspecific adsorption is 0.086 and 0.022

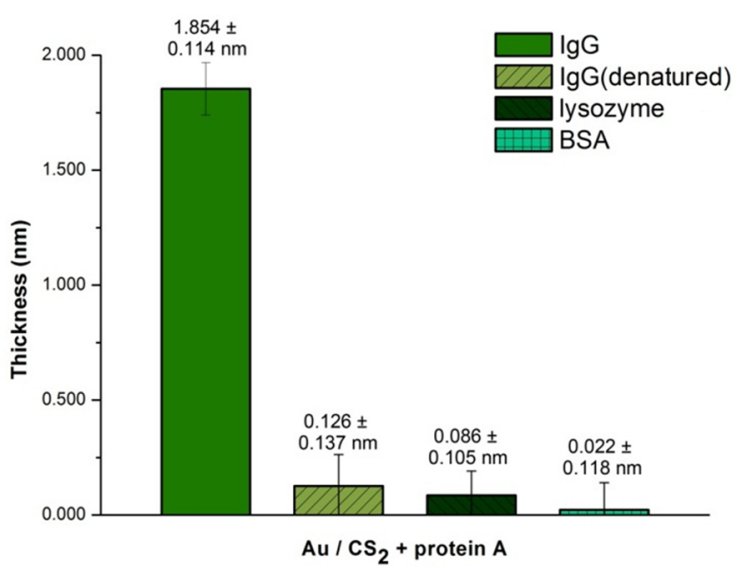

Figure 9. Ellipsometric results of control experiment for the capability to inhibit nonspecific adsorption with lysozyme and BSA.

$\mathrm{nm}$ for lysozyme and BSA, respectively. Compared to the change of native IgG, such an increase will certainly not affect the main result. When blocking agents, such as gelatin, casein, or BSA, are used on the modified surface, the effect of nonspecific adsorption should be further impaired.

\section{CONCLUSIONS}

The feasibility of antibody-oriented immobilization on gold surface using the one-step adsorption of protein $\mathrm{A}$ and $\mathrm{CS}_{2}$ is demonstrated. By simply immersing a gold slide into a mixed solution of $\mathrm{CS}_{2}$ and protein $\mathrm{A}$, protein $\mathrm{A}$ is validated to be covalently bound to the gold surface by the interaction between gold, $\mathrm{CS}_{2}$, and the amine group of protein $\mathrm{A}$, as evidenced by electrochemical reductive desorption experiments, UV-vis adsorption spectroscopy. The capture of $\mathrm{IgG}$, as a typical kind of antibody, by immobilized protein $\mathrm{A}$ and its further interaction with anti-IgG have been monitored by ellipsometry, SPR, and AFM. A number of control experiments, including the direct adsorption of IgG on gold surface and the introduction of denatured IgG and anti-IgG molecules, reflect that the better sensitivity to capture IgG was achieved for gold modified with protein $\mathrm{A}$ and $\mathrm{CS}_{2}$, revealing the potential application of the one-step in situ dithiocarbamate formation in the preparation of immunosensors. The good ability of the modified surface to inhibit nonspecific adsorption, in the absence of any blocking agent, is also proven by the extremely low changes of the optical parameters after incubation with denatured IgG or AntiIgG solutions. To conclude, antibody can be successfully immobilized using this simple, effective, and practical approach to form an immunosensing surface, which combines good sensitivity and strong capability to inhibit nonspecific adsorption.

\section{ASSOCIATED CONTENT}

\section{S Supporting Information}

Ellipsometric parameters obtained for distinct IgG modified surfaces upon exposure to different anti-IgG concentrations. This material is available free of charge via the Internet at http://pubs.acs.org. 


\section{AUTHOR INFORMATION}

\section{Corresponding Author}

*Tel. /Fax: +351 217500000/+351 217500088, e-mail anaviana@fc.ul.pt (Ana S. Viana). Tel. /Fax: +86 10 82544138, e-mail gajin@imech.ac.cn (Gang Jin).

Notes

The authors declare no competing financial interest.

\section{ACKNOWLEDGMENTS}

The authors acknowledge the financial support to the sixth Sino-Portugal Scientific and Technological Cooperation of 2010-2012, to Portuguese Science Foundation (Bilateral cooperation FCT/P. R. China, projects PTDC/QUI/66612/ 2006, PEst-OE/QUI/UI0612/2011, and Programme Ciência 2007), and to the International Science \& Technology Cooperation Program of China (2012DFG31880), and to the National Basic Research Program of China (2009CB320302).

\section{REFERENCES}

(1) D’Orazio, P. Biosensors in Clinical Chemistry: 2011 Update. Clin. Chim. Acta 2011, 412, 1749-1761.

(2) D'Orazio, P. Biosensors in Clinical Chemistry. Clin. Chim. Acta 2003, 334, 41-69.

(3) Luong, J. H. T.; Male, K. B.; Glennon, J. D. Biosensor Technology: Technology Push versus Market Pull. Biotechnol. Adv. 2008, 26, 492-500.

(4) Liedberg, B.; Nylander, C.; Lundstrom, I. Surface Plasmon Resonance for Gas Detection and Biosensing. Sens. Actuators 1983, 4, 299-304.

(5) Li, Y.; Liu, X.; Lin, Z. Recent Developments and Applications of Surface Plasmon Resonance Biosensors for the Detection of Mycotoxins in Foodstuffs. Food Chem. 2012, 132, 1549-1554.

(6) Hunt, H. K.; Armani, A. M. Label-free Biological and Chemical Sensors. Nanoscale 2010, 2, 1544-1559.

(7) Wu, X. L.; Kuang, H.; Hao, C. L.; Xing, C. R.; Wang, L. B.; Xu, C. L. Paper Supported Immunosensor for Detection of Antibiotics. Biosens. Bioelectron. 2012, 33, 309-312.

(8) Holford, T. R. J.; Davis, F.; Higson, S. P. J. Recent Trends in Antibody Based Sensors. Biosens. Bioelectron. 2012, 34, 12-24.

(9) Matharu, Z.; Bandodkar, A. J.; Gupta, V.; Malhotra, B. D. Fundamentals and Application of Ordered Molecular Assemblies to Affinity Biosensing. Chem. Soc. Rev. 2012, 41, 1363-1402.

(10) Gerard, M.; Chaubey, A.; Malhotra, B. D. Application of Conducting Polymers to Biosensors. Biosens. Bioelectron. 2002, 17, $345-359$.

(11) Frasconi, M.; Mazzei, F.; Ferri, T. Protein Immobilization at Gold-thiol Surfaces and Potential for Biosensing. Anal. Bioanal. Chem. 2010, 398, 1545-1564.

(12) Hu, W.; Lu, Z.; Liu, Y.; Li, C. M. In Situ Surface Plasmon Resonance Investigation of the Assembly Process of Multiwalled Carbon Nanotubes on an Alkanethiol Self-Assembled Monolayer for Efficient Protein Immobilization and Detection. Langmuir 2010, 26, 8386-8391.

(13) Ulman, A. Formation and Structure of Self-assembled Monolayers. Chem. Rev. 1996, 96, 1533-1554.

(14) Limbut, W.; Kanatharana, P.; Mattiasson, B.; Asawatreratanakul, P.; Thavarungkul, P. A Comparative Study of Capacitive Immunosensors Based on Self-assembled Monolayers Formed from Thiourea, Thioctic Acid, and 3-mercaptopropionic Acid. Biosens. Bioelectron. 2006, 22, 233-240.

(15) Love, J. C.; Estroff, L. A.; Kriebel, J. K.; Nuzzo, R. G.; Whitesides, G. M. Self-assembled Monolayers of Thiolates on Metals as A Form of Nanotechnology. Chem. Rev. 2005, 105, 1103-1169.

(16) Prime, K. L.; Whitesides, G. M. Self-assembled Organic Monolayers: Model Systems for Studying Adsorption of Proteins at Surfaces. Science 1991, 252, 1164-1167.
(17) Flink, S.; van Veggel, F.; Reinhoudt, D. N. Sensor Functionalities in Self-assembled Monolayers. Adv. Mater. 2000, 12, 1315-1328.

(18) Schlenoff, J. B.; Li, M.; Ly, H. Stability and Self-exchange in Alkanethiol Monolayers. J. Am. Chem. Soc. 1995, 117, 12528-12536.

(19) Wang, Z. H.; Viana, A. S.; Jin, G.; Abrantes, L. M. Immunosensor Interface Based on Physical and Chemical Immunogylobulin G Adsorption onto Mixed Self-assembled Monolayers. Bioelectrochemistry 2006, 69, 180-186.

(20) Yang, X. Y.; Guo, Y. S.; Wang, A. G. Luminol/antibody Labeled Gold Nanoparticles for Chemiluminescence Immunoassay of Carcinoembryonic Antigen. Anal. Chim. Acta 2010, 666, 91-96.

(21) Tiekink, E. R. T. Tin Dithiocarbamates: Applications and Structures. Appl. Organomet. Chem. 2008, 22, 533-550.

(22) Colorado, R; Villazana, R. J.; Lee, T. R. Self-assembled Monolayers on Gold Generated from Aliphatic Dithiocarboxylic Acids. Langmuir 1998, 14, 6337-6340.

(23) Morf, P.; Raimondi, F.; Nothofer, H. G.; Schnyder, B.; Yasuda, A.; Wessels, J. M.; Jung, T. A. Dithiocarbamates: Functional and Versatile Linkers for the Formation of Self-assembled Monolayers. Langmuir 2006, 22, 658-663.

(24) Cao, R.; Diaz-Garcia, A. M.; Cao, R. Coordination Compounds Built on Metal Surfaces. Coord. Chem. Rev. 2009, 253, 1262-1275.

(25) Zhao, Y.; Perez-Segarra, W.; Shi, Q. C.; Wei, A. Dithiocarbamate Assembly on Gold. J. Am. Chem. Soc. 2005, 127, 7328-7329.

(26) Zhu, H.; Coleman, D. M.; Dehen, C. J.; Geisler, I. M.; Zemlyanov, D.; Chmielewski, J.; Simpson, G. J.; Wei, A. Assembly of Dithiocarbamate-anchored Monolayers on Gold surfaces in Aqueous Solutions. Langmuir 2008, 24, 8660-8666.

(27) Eckermann, A. L.; Shaw, J. A.; Meade, T. J. Kinetic Dispersion in Redox-Active Dithiocarbamate Monolayers. Langmuir 2010, 26, 2904-2913.

(28) Almeida, I.; Cascalheira, A. C.; Viana, A. S. One Step Gold (Bio)functionalisation Based on $\mathrm{CS}_{2}$-amine Reaction. Electrochim. Acta 2010, 55, 8686-8695.

(29) Gao, D. Q.; Scholz, F.; Nothofer, H. G.; Ford, W. E.; Scherf, U.; Wessels, J. M.; Yasuda, A.; von Wrochem, F. Fabrication of Asymmetric Molecular Junctions by the Oriented Assembly of Dithiocarbamate Rectifiers. J. Am. Chem. Soc. 2011, 133, 5921-5930.

(30) Chen, K.; Robinson, H. D. J. Robust dithiocarbamate-anchored amine functionalization of Au nanoparticles. Nanoparticle Res 2011, 13, $751-761$.

(31) Zhang, Y. J.; Schnoes, A. M.; Clapp, A. R. Dithiocarbamates as Capping Ligands for Water-Soluble Quantum Dots. ACS Appl. Mater. Interfaces 2010, 2, 3384-3395.

(32) Morf, P.; Ballav, N.; Putero, M.; von Wrochem, F.; Wessels, J. M.; Jung, T. A. Supramolecular Structures and Chirality in Dithiocarbamate Self-Assembled Monolayers on $\mathrm{Au}(111)$. J. Phys. Chem. Lett. 2010, 1, 813-816.

(33) Wei, A. Calixarene-encapsulated Nanoparticles: Self-assembly into Functional Nanomaterials. Chem. Commun. 2006, 15, 1581-1591.

(34) Leonov, A. P.; Wei, A. Photolithography of Dithiocarbamateanchored Monolayers and Polymers on Gold. J. Mater. Chem. 2011, 21, 4371-4376.

(35) Sharma, J.; Chhabra, R.; Yan, H.; Liu, Y. A Facile In Situ Generation of Dithiocarbamate Ligands for Stable Gold Nanoparticleoligonucleotide Conjugates. Chem. Commun. 2008, 18, 2140-2142.

(36) Wang, Z. H.; Jin, G. Feasibility of Protein A for the Oriented Immobilization of Immunoglobulin on Silicon Surface for a Biosensor with Imaging Ellipsometry. J. Biochem. Biophys. Methods 2003, 57, 203-211.

(37) Cabrita, J. F.; Viana, A. S.; Eberle, C.; Montforts, F. P.; Mourato, A.; Abrantes, L. M. Electrooxidation of Pyrrole-terminated Selfassembled Lipoic Acid Derivatives. Surf. Sci. 2009, 603, 2458-2462.

(38) Petersso, B.; Sjoquist, J. Some Physicochemical Properties of Protein A from Staphylococcus Aureus. Eur. J. Biochem. 1972, 29, 579582. 
(39) Arwin, H. Optical-properties of Thin-layers of Bovine Serum Albumin, Gamma Globulin and Hemoglobin. Appl. Spectrosc. 1986, 40, 313-318.

(40) Meunier-Prest, R.; Legay, G.; Raveau, S.; Chiffot, N.; Finot, E. Potential-assisted Deposition of Mixed Alkanethiol Self-assembled Monolayers. Electrochim. Acta 2010, 55, 2712-2720.

(41) Pace, C. N.; Vajdos, F.; Fee, L.; Grimsley, G.; Gray, T. How to Measure and Predict the Molar Absorption Coefficient of a Protein. Protein Sci. 1995, 4, 2411-2423.

(42) von Wrochem, F.; Gao, D. Q.; Scholz, F.; Nothofer, H. G.; Nelles, G.; Wessels, J. M. Efficient Electronic Coupling and Improved Stability with Dithiocarbamate-based Molecular Junctions. Nat. Nanotechnol. 2010, 5, 618-624.

(43) Wang, Z. H.; Jin, G. Covalent Immobilization of Proteins for the Biosensor Based on Imaging Ellipsometry. J. Immunol. Methods 2004, 285, 237-243. 